Doi: HTTPS://DOI.ORG/10.23910/IJBSM/2017.8.4.1719

\title{
Market Efficiency of Rubber: An Analytical Study Based on Co-integration Technique
}

\author{
M. P. Sharath Kumar ${ }^{1^{*}}$, P. R. Suresh ${ }^{2}$ \\ ${ }^{1}$ Kerala Agricultural University, College of Agriculture, Vellayani, Trivandrum, Kerala (695 522), India \\ ${ }^{2}$ Kerala University of Fisheries and Ocean Studies, Kochi, Kerala (682 506), India
}

\section{Corresponding Author}

M. P. Sharath Kumar

e-mail: gsharath.kumar3@gmail.com

\author{
Article History \\ Article ID: AR1719 \\ Received in $26^{\text {th }}$ October, 2016 \\ Received in revised form $25^{\text {th }}$ July, 2017 \\ Accepted in $6^{\text {th }}$ August, 2017
}

\begin{abstract}
India is the fourth largest producer of Natural Rubber which accounts 7\% of world production. It is found that more than 12 lakh farmers directly depend on Natural Rubber for their livelihood strategies. When we analyses the global Natural Rubber market, we can see that in the recent years there is a sharp decline in the market prices of Natural Rubber at internationally and domestically. The present study analyses the interdependence of domestic and international market prices with the use of Co-integration technique to prove market efficiency. The integration of rubber market is measured by using the time series data from 2012-2015. By taking the data on rubber prices in the Kottayam market in India as domestic price, and Bangkok rubber market as the international price. Error Correction Model (ECM) for long run relationship and Granger Causality tests were also used for an in-depth analysis. The Granger test result indicates that there is causality in at least one direction, i.e. Bangkok price causes the price in Indian market as the $p$-value is 0.0399 which is less than level of significance at $5 \%$. Overall, there is sufficient evidence to conclude that Indian rubber market is integrated with the Bangkok market in the long-run. The recent fall in domestic price of Natural Rubber was due to a fall in the international price.
\end{abstract}

Keywords: Natural rubber, co-integration, causality, price, market, domestic

\section{Introduction}

There was rapid increase in the global demand for Natural Rubber (NR) in the past decade and it is also expected to increase for the coming years. The NR world consumption is $12.3 \mathrm{mt}$ for the 2015-16 (Rubber statistical news, 2016) and it estimated to reach $16.5 \mathrm{mt}$ in 2023 (Rubber study, 2015). In the production of NR, India stands fourth position where Thailand leads the production followed by Indonesia and Malaysia. Production of Natural Rubber (NR) in India during the year 2015-16 fell $12.9 \%$ to 562,000 t from 645,000 t produced a year ago. The output registered lowest in about last five years. The sharp decline in the production of NR is caused by fall in the prices at international level. The price ruled around ₹ $220 \mathrm{~kg}^{-1}$ in January 2011 came down to $111.5 \mathrm{~kg}^{-1}$ at the $3^{\text {rd }}$ quarter of 2015-2016. The fall in the international rubber price resulted from the plummeting crude oil price and restrictions on the import of rubber by China (Krishna, 2015). In the country, about $85 \%$ of the Natural Rubber is produced in Kerala providing livelihood options for 12 lakh farmers (The New Indian Express, 2015). The decline in the domestic rubber prices is creating worries in the Minds of rubber growers. The present study tries to analyses the interdependence of domestic and international rubber market.

The persistent fall in the rubber prices causes concern among the rubber farmers in India. Table 1 indicates the average price of RSS-4 at Kottayam from 2006-07 to 2015-16. It is evident from the table that the average price of Natural Rubber stood

\begin{tabular}{lc}
\hline \multicolumn{2}{l}{ Table 1: Average price of RSS-4 at Kottayam, Kerala } \\
\hline Year & ₹ $100 \mathrm{~kg}^{-1}$ \\
\hline $2006-07$ & 9204 \\
$2007-08$ & 9085 \\
$2008-09$ & 10112 \\
$2009-10$ & 11498 \\
$2010-11$ & 19003 \\
$2011-12$ & 20805 \\
$2012-13$ & 17682 \\
$2013-14$ & 16602 \\
$2014-15$ & 13257 \\
$2015-16^{\mathrm{P}}$ & 11306 \\
\hline
\end{tabular}

Source: Rubber board, 2016; P: provisional 
high during the year 2011-12. Thereafter, we can see sharp decline in the average rubber prices of RSS- 4 grade to reach Rs $11306 \mathrm{~kg}^{-1}$ at the end of $1^{\text {st }}$ quarter 2016 . The rising cost of production as a result of rise in wages and cost of fertilizers, the growers decided to stay away from production. This resulted in the decrease of output during the past year. The present study analyses the Co-integration between international and domestic rubber markets and examines whether the decline in the market prices was resulted from the fall in international prices or not.

\subsection{Objectives of the study}

The important objectives of the study are:

To examine the co-integrated relationship between domestic and international market prices of rubber.

To determine causality between international and domestic rubber prices.

\section{Materials and Methods}

\subsection{Collection data}

The present study uses secondary data for the analysis and interpretation. Rubber prices are collected from Rubber Board of India where price prevailing in Bangkok is considered as price of international market and Kottayam market price is preferred for domestic market price. At international and domestic level, the prices of grade RSS-3 and RSS- 4 were chosen where RSS-3 for Bangkok market and the latter one for Indian market. Daily prices of natural rubber from the period of 02/07/2012 to $30 / 06 / 2015$ were collected and analyzed. During this period, the market witnessed sharp decline in the NR prices.

\subsection{Methodology}

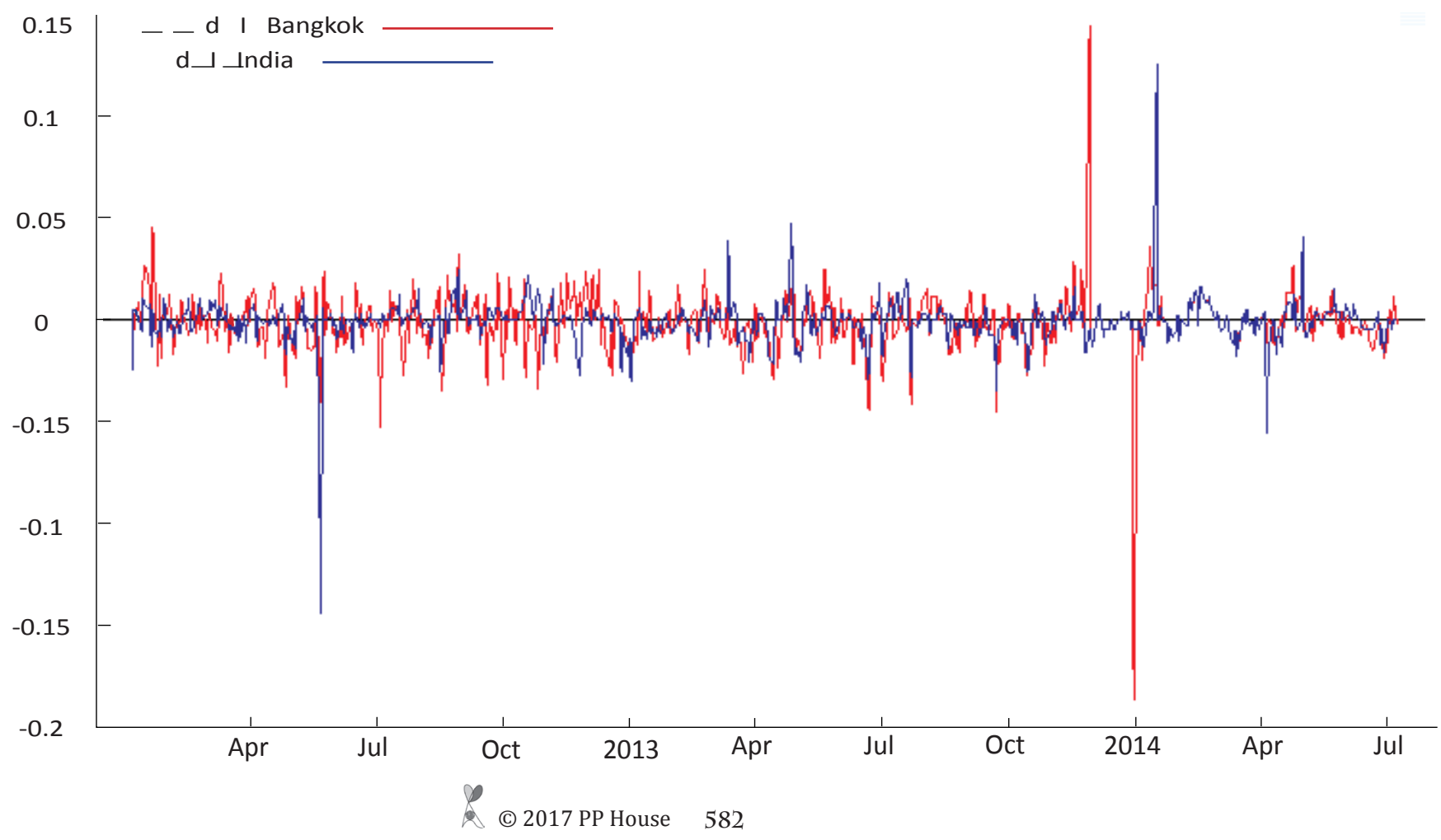

Co-integration of markets is analyzed with the help of Englegranger test. Error correction model provides the consistency of co-integration. There are a few studies related to Cointegration of rubber markets. But these studies are more regions specific. In a study by Fathoni (2009) analyzed the market system and market integration for rubber cultivation in Jambi Province Indonesia. They used Johansen Co-integration technique and Granger causality test. The result showed that there is no significant integration for both the markets.

Philip (2008) analyzed rubber price in Kerala for pre and postreform period and found that during post-reform period the market is co-integrated. He selected two regional rubber markets in Kerala and done co-integration of these markets. Kannan (2013); Grafoute and Yao (2012) adopted least squares method to determinants of production and export of NR in India, they found that export of Natural Rubber is positively influencing by world market price, world population, domestic rubber production and producer price.

In order to determine the nature of each bivariate relationship of the movement of the causality the study used Granger tests. Data analysis is done using Gretl software.

\section{Results and Discussion}

Time series data on the daily prices of rubber in domestic market i.e. Kottayam and international market i.e. Bangkok for the period from $2 / 7 / 2012$ to $30 / 06 / 2015$ was used for the analysis. The concept of Co-integration and Error Correction Model was used to analyze the co-movement of rubber price in domestic and international market and the extent of transmission of international prices to domestic market. The graph of the logarithmic value of two price series is presented in Figure 1. There is a high volatility with respect 
to both international and domestic market prices of Natural Rubber. It found to be non-stationary. To make it stationary, first difference is taken and the time series plot for the same is depicted in Figure 2. Now the variables are found to be

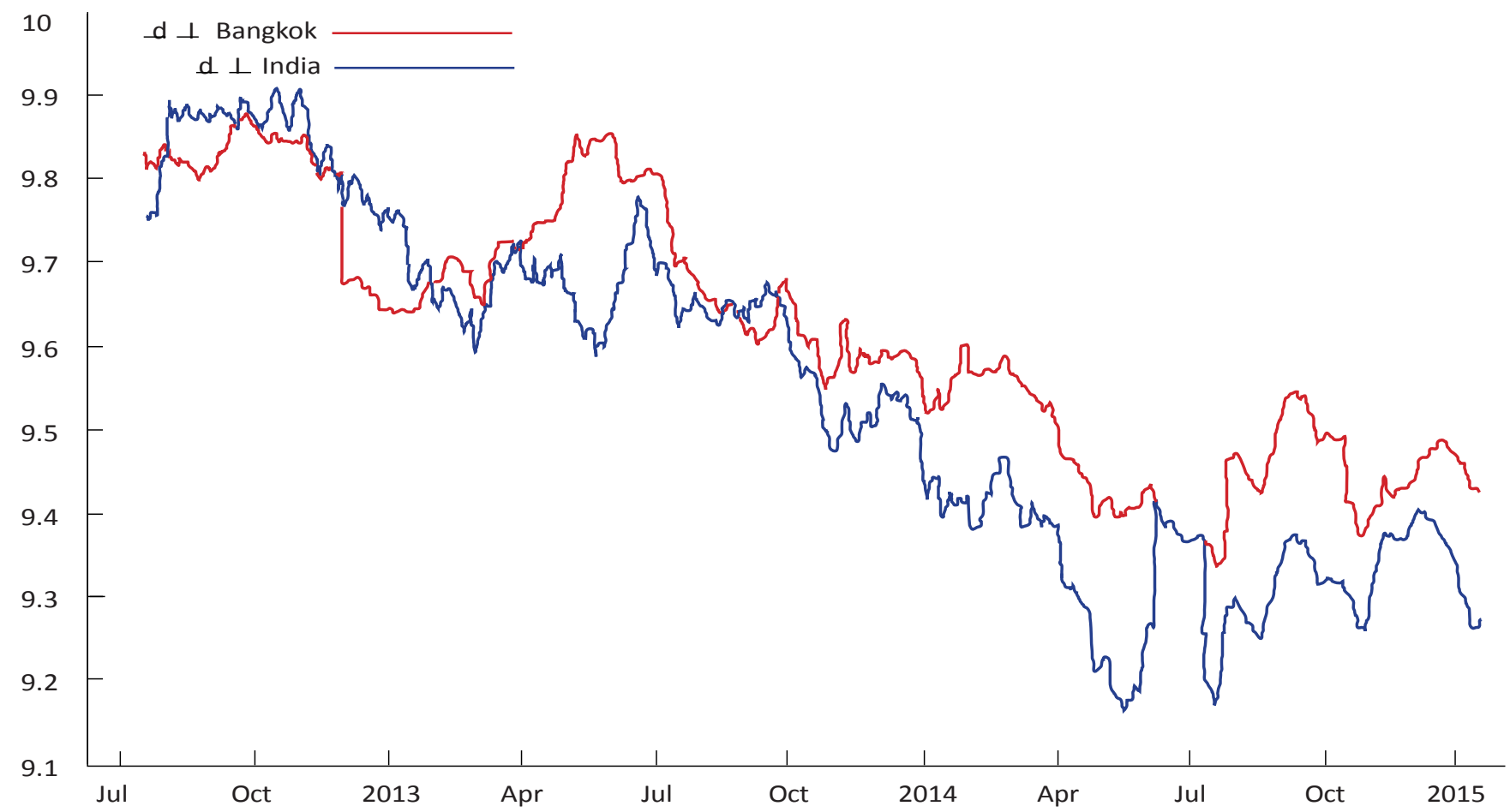

stationary.

Table 2 gives ADF test (Dickey and fuller, 1979) results of domestic and international price. The null hypothesis i.e. $\delta=0$ (there is a unit root) is rejected by comparing asymptotic critical

Table 2: ADF test for stationary of domestic and international price

\begin{tabular}{lccccc}
\hline No. of lags & \multicolumn{2}{c}{ Indian price } & & \multicolumn{2}{c}{ Bangkok price } \\
\cline { 2 - 3 } & Level & $\begin{array}{c}\text { Differ- } \\
\text { ence }\end{array}$ & & Level & $\begin{array}{c}\text { Differ- } \\
\text { ence }\end{array}$ \\
\hline $\begin{array}{l}\text { Lag one with } \\
\text { trend }\end{array}$ & -2.35189 & -15.5374 & -3.05135 & -15.7818 \\
$\begin{array}{l}\text { Lag one with- } \\
\text { out trend }\end{array}$ & -1.04827 & -15.5491 & -0.85404 & -15.7905 \\
$\begin{array}{l}\text { Lag four with } \\
\text { trend }\end{array}$ & -2.35189 & -10.9821 & -3.05135 & -10.9885 \\
$\begin{array}{l}\text { Lag four with- } \\
\text { out trend }\end{array}$ & -1.04827 & -10.9902 & -0.85404 & -10.9952 \\
\hline
\end{tabular}

values i.e., Mackinnon critical values for lag 4 and 1 without trend @ 1\%, 5\%, 10\% are -3.35, -3.14, - 2.57 and for same lags with trend are $-3.98,-3.43$, and -3.13 . The ADF test values were more than asymptotic critical values suggest that were stationary after differencing once. It reveals that price series were not stationary in the level form but attains stationary after differencing once or integrated of order I (1).

After unit root test is done and all variables indicate that I (1), the next step is to test co integration between two variables utilizing Engle-Granger Co-integration test (Engle and Granger, 1989). The result of the Co-integration test is depicted in Table 3.

The estimated values of the co-integrating coefficients first difference of Bangkok, one lag of differenced Indian price series were $0.224980,0.168649$ respectively show high degree of association between two market prices. ADF test is helpful to identify co-movement of the price series. It indicates that both the series are co-integrated, but it do not provide any evidence for the extent of integration in terms of short-run and long-run correction for equilibrium price. For this purpose error correction model is necessary.

\begin{tabular}{lc}
\hline \multicolumn{2}{l}{ Table 3: Results of co-integrating regression } \\
\hline Independent variables & Dependent variable: d_I_India \\
\hline constant & -0.000332221 \\
d_I_Bangkok & 0.224980 \\
d_I_India_1 & 0.168649 \\
Adjusted R-squared & 0.127837 \\
Durbin's h & -0.308846 \\
Akaike criterion & -4184.729 \\
Hannan-Quinn & -4179.509 \\
ADF of residuals & -15.669 \\
\hline
\end{tabular}

For getting co-integration between two markets prices, it is necessary that at least one of ECM co-efficient is should be negative and significant. It is evident from the Table 4 that the two series are strongly co-integrated and at least one way of 


\begin{tabular}{lcccc}
\hline Table 4: Error correction model (ECM) estimates \\
\hline $\begin{array}{l}\text { Depen- } \\
\text { dent } \\
\text { variable }\end{array}$ & Constant & EC1 & $p$-value & $\begin{array}{c}\text { Adjusted } \\
\text { R squared }\end{array}$ \\
\cline { 2 - 5 } d_I_India & $1.14267 \mathrm{e}-$ & -0.416694 & $1.33 \mathrm{e}-$ & 0.152422 \\
& 05 & & $025^{* * *}$ & \\
d_I_ & $2.69059 \mathrm{e}-$ & 0.584279 & $2.44 \mathrm{e}-$ & 0.162599 \\
Bangkok & 05 & & $027^{* * *}$ & \\
\hline${ }^{* * *} p<0.001$ & & &
\end{tabular}

co-integration is present. So to know the way of co-integration, we have to test for Granger Causality test.

The Granger test result indicates that there is causality in at least one direction (Table 5). The null hypothesis is rejected i.e. Bangkok price does not cause the price in Indian market

Table 5: Granger causality test result

\begin{tabular}{lcc}
\hline Null hypothesis & F-Statistic & $p$-value \\
\hline $\begin{array}{l}\text { India does not granger cause } \\
\text { Bangkok }\end{array}$ & 0.72677 & 0.4839 \\
$\begin{array}{l}\text { Bangkok does not granger cause } \\
\text { India }\end{array}$ & 3.24028 & $0.0399^{*}$ \\
\hline$* p<0.05$ & & \\
\hline
\end{tabular}

as the $p$-value is 0.0399 which is less than level of significance at $5 \%$. Overall, there is sufficient evidence to conclude that Indian rubber market is integrated with the Bangkok market in the long-run. It can be concluded that Bangkok rubber market price causes market price of India. So it can be inferred that the recent fall in price was caused by the fall in international price of Natural Rubber.

\section{Conclusion}

The current price and lagged price in both markets are considered as variables that explains the market integration. Based on the co-integration analysis, it is evident that both domestic and international rubber prices are co-integrated. The Granger Causality showed that there is causality in at least one direction that the Bangkok price causes the price in Indian market. The recent fall in domestic price of Natural Rubber was due to a fall in the international price.

\section{References}

Dickey, D.A., Fuller, W.A., 1979. Distribution of Estimators for Time Series Regressions with a Unit Root, Journal of the American Statistical Association 74(2), 427-431.

Engle, R.F., Granger, C.W.J., 1989. Co-integration and error correction: representation, estimation and testing. Econometrica 55(2), 251-276.

Fathoni, Z., 2009. Evaluation of Market system and Market integration for Rubber cultivation in Jambi ProvinceIndonesia. Thesis report, Wageningen University and Research, Wageningen, 58-67.

Grafoute, A., Yao, S., 2012. The determinants of Agricultural Export: Cocoa and Rubber in Cote d'Ivore. International Journal of Economics and Finance 1(5), 89-93.

Kannan, M., 2013. The Determinants of Production and Export of Natural Rubber In India. An Exploratory Analysis. Journal of Economics and Finance 5(1), 41-45.

Krishna, P.K., 2015. Rubber output shrinks by $36 \%$, demand slows. The Economic times, accessed on $12^{\text {th }}$ August, 2015. Available from: http://bhuaip.org/13012015.pdf.

Philip, A., 2008. An analytical study of market integration hypothesis for natural rubber cultivation of Kerala. Icfai University. Journal of Agricultural Economics 5(2), 31-40.

Rubber Board, 2016. Domestic Rubber Price, Government of India. Accessed on $12^{\text {th }}$ August 2016. Available from http://rubberboard.org.in/reports/statisticalhighlights. pdf

Rubber Study, 2015. Latest World Rubber Industry Outlook now available from IRSG. News article, accessed on $11^{\text {th }}$ August 2015. http://www.rubberstudy.com/newsarticle. aspx id $=5081 \& b=$ default. $a s p x$.

RSN (Rubber Statistical News), 2016. Rubber statistical bulletin (April-June 2016) of international rubber study group. statistics \& planning department rubber board, Kottayam, Kerala 12(74), 4-8.

The New Indian Express, 2015. News on rubber price. Accessed on $12^{\text {th }}$ August 2015 available from: http:// www.newindianexpress.com/business/news/RubberGrowers-Face-Uncertain-Future-with-32.7-Fall-inPrice/2015/02/20/article2677580.ece. 